ISSN: 1858-4837;E-ISSN: 2598-019X

Volume 16, Nomor 1 (2021)

https://jurnal.uns.ac.id/region

DOI: 10.20961/region.v16i1.35219

\title{
Partisipasi masyarakat dalam pengembangan kawasan wisata Tirtasari Sonsang Kabupaten Agam
}

\author{
Community participation in development of Tirtasari Sonsang tourism area, \\ Agam Regency
}

\author{
T Nabila ${ }^{1}$, J Purwohandoyo ${ }^{2}$ \\ ${ }^{1}$ Mahasiswa, Departemen Geografi Pembangunan, Fakultas Geografi, UGM \\ ${ }^{2}$ Dosen, Departemen Geografi Pembangunan, Fakultas Geografi, UGM
}

Corresponding author's email: tsurayya3424@gmail.com

\begin{abstract}
Abstrak. Pariwisata berbasis masyarakat adalah salah satu pendekatan yang digunakan untuk mengembangkan sektor pariwisata satu daerah. Wisata Tirtasari Sonsang melibatkan masyarakat dalam pengembangannya. Tujuan penelitian ini adalah untuk mengidentifikasi bentuk partisipasi masyarakat, menganalisis intensitas partisipasi masyarakat, dan menganalisis faktor-faktor yang berpengaruh dalam partisipasi masyarakat Jorong Sonsang. Metode penelitian yang digunakan adalah metode kualitatif dengan teknik analisis deskriptif kualitatif untuk menggambarkan fakta yang ditemukan di lapangan. Hasil menunjukkan masyarakat Jorong Sonsang memiliki bentuk partisipasi berupa kemitraan dan mobilisasi dengan kemauan sendiri atau interactive participation dan self-mobilization, serta partisipasi langsung dan tidak langsung. Berdasarkan matriks cakupan dan intensitas partisipasi, partisipasi masyarakat Jorong Sonsang termasuk ke dalam genuine participation atau skenario kelima. Faktor yang berpengaruh dalam partisipasi masyarakat Jorong Sonsang adalah motivasi untuk meramaikan Jorong Sonsang, rasa memiliki yang kuat terhadap embung Tirtasari, memiliki kemampuan yang dibutuhkan, serta keinginan untuk meningkatkan perekonomian masyarakat.
\end{abstract}

Kata Kunci: Pariwisata Berbasis Masyarakat; Partisipasi; Pengembangan Wisata

Abstract. Community-based tourism is an approach used to develop tourism sector.
Tirtasari Sonsang as a tourist attraction involves the community in its development.
The purpose of this study is to identify forms of community participation, to analyze
the intensity of community participation, and to analyze factors that influence the

Received : October 28, 2019; Accepted: January 23, 2019; Available online: January 30, 2021

Copy right @ 2021, REGION: Jurnal Pembangunan Wilay ah dan Perencanaan Partisipatif 
community participation. This study used qualitative method with qualitative descriptive as analysis technique to describe the fact that had been found. The results showed that form of community participation in Jorong Sonsang are partnership, interactive participation, and self-mobilization. They also have direct and indirect participation. According to scope-intensity matrix, community participation in Jorong Sonsang is classified as genuine participation or the fifth scenario. Factors that affect community participation in Jorong Sonsang are the motivation to revive Jorong Sonsang, a strong sense of belonging to the Tirtasari reservoir, have the skills that needed, and desire to improve community economy.

Keywords: Community-Based Tourism; Participation; Tourism Development

\section{Pendahuluan}

Berdasarkan Peraturan Menteri Nomor 14 Tahun 2016 [1], pariwisata di Indonesia dikembangkan dengan pendekatan pertumbuhan dan pemerataan ekonomi untuk mencapai kesejahteraan masyarakat. Oleh karena itu pembangunan pariwisata bertumpu pada masyarakat dan memberdayakan masyarakat tersebut. Masyarakat dijadikan sebagai subjek dalam pengembangan pariwisata karena masyarakat memiliki pengetahuan yang mendalam mengenai lingkungannya. Pembangunan pariwisata ini disebut dengan pariwisata berbasis masyarakat. Pariwisata berbasis masyarakat atau yang biasa disebut dengan CommunityBased Tourism menurut WWF dalam Goodwin dan Santilli [2], merupakan konsep pariwisata yang mana masyarakat memiliki kuasa dan keterlibatan yang dalam terhadap pengembangan dan pengelolaannya, sehingga masyarakat mendapatkan manfaat dari sektor pariwisata secara langsung. Pariwisata berbasis masyarakat menjadikan masyarakat sebagai subjek dari kegiatannya. Partisipasi masyarakat merupakan hal yang penting dalam pengembangan pariwisata, sehingga pariwisata akan berkembang dengan basis dan orientasi kepada masyarakat [3]. Partisipasi menurut Davis dalam Karim dkk [4] didefinisikan sebagai keterlibatan individu dalam suatu kelompok, baik secara mental dan emosional agar dapat mendukung dan menunjang tujuan-tujuan kelompok tersebut serta bertanggung jawab terhadap tujuan kelompok tersebut.

Partisipasi yang diberikan oleh masyarakat berbeda-beda sesuai dengan kemampuan masyarakat. Partisipasi yang diberikan oleh masyarakat dapat dikelompokkan menjadi beberapa bentuk. Steck dalam Damanik dan Weber [5] mengelompokkan bentuk partisipasi berdasarkan sifat partisipasi yang diberikan oleh masyarakat. Sifat partisipasi tersebut dapat dikelompokkan menjadi partisipasi langsung, tidak langsung, dan partisipasi nol.

Wardiyanto dan Baiquni [6] mengelompokkan partisipasi menjadi enam bentuk yang terdiri atas pemberitahuan, pengumpulan informasi, perundingan, konsiliasi, kemitraan, dan mobilisasi dengan kemauan sendiri. Bentuk partisipasi ini memiliki kemiripan dengan bentuk partisipasi yang dikemukakan oleh France dalam Breugel [7]. France mengemukakan bentuk partisipasi berdasarkan keterlibatan pihak eksternal dan kontrol masyarakat secara internal yang meliputi plantation, manipulative and passive participation, consultation, material incentive, functional participation, interactive participation, dan self-mobilization. 
Li et al [8] mengembangkan matriks cakupan-intensitas untuk menggambarkan partisipasi masyarakat dalam pengembangan wisata. Matriks tersebut terdiri atas cakupan dan intensitas partisipasi. Cakupan merupakan keterjangkauan masyarakat yang terlibat dalam suatu kegiatan apakah telah mewakili seluruh kelompok kepentingan yang ada. Li mengelompokkan cakupan partisipasi tersebut menjadi tiga jenis, yaitu exclusion, partial participation, dan full participation. Intensitas menggambarkan sejauh mana keterlibatan masyarakat dalam suatu kegiatan. Partisipasi akan menjadi semakin intens apabila masyarakat dilibatkan secara langsung serta terdapat dialog antar stakeholder yang terlibat secara terbuka dan saling menghormati. Li mengelompokkan intensitas partisipasi menjadi tiga jenis, yaitu exclusion, passive participation, dan active participation.

Kabupaten Agam adalah salah satu kabupaten di Sumatera Barat yang gencar mengembangkan kegiatan pariwisatanya. Posisi Kabupaten Agam yang strategis mendukung kabupaten ini agar mudah dikunjungi oleh wisatawan dari berbagai daerah. Salah satu objek wisata yang dikembangkan di Kabupaten Agam yaitu Tirtasari Sonsang yang ada di Kecamatan Tilatang Kamang. Wisata Tirtasari Sonsang ini memiliki daya tarik berupa embung yang telah lama dikelola oleh masyarakat. Tidak hanya menawarkan daya tarik alam dan embung, objek wisata Tirtasari juga memiliki daya tarik berupa rumah kurcaci yang dibangun di sela-sela tebing berbatu. Pengembangan wisata Tirtasari Sonsang tersebut melibatkan masyarakat dalam pengelolaannya. Masyarakat berinisiasi untuk mengembangkan dan mengelola potensi yang dimiliki oleh daerahnya sebagai daya tarik objek wisata Tirtasari Sonsang. Partisipasi masyarakat dalam pengembangan wisata Tirtasari Sonsang merupakan aspek utama yang harus dikembangkan agar wisata Tirtasari Sonsang dapat berjalan secara optimal sehingga dapat memberikan manfaat dan keuntungan terhadap masyarakat sekitar.

Terdapat beberapa faktor yang berpengaruh terhadap partisipasi masyarakat. Faktor yang berpengaruh tersebut dapat dikelompokkan menjadi dua faktor, yaitu faktor internal dan faktor eksternal [9]. Faktor internal adalah faktor yang berasal dari diri seorang individu seperti faktor mutu modal manusia, pemahaman, dan motivasi individu. Sedangkan faktor eksternal adalah faktor yang berasal dari luar individu seperti kepemimpinan, komunikasi, manajemen, dan sosial budaya. Tujuan penelitian ini terdiri atas sebagai berikut:

1. Mengidentifikasi bentuk partisipasi masyarakat dalam pengembangan wisata Tirtasari Sonsang Kabupaten Agam.

2. Menganalisis intensitas partisipasi masyarakat dalam pengembangan wisata Tirtasari Sonsang Kabupaten Agam.

3. Menganalisis faktor-faktor yang berpengaruh terhadap partisipasi masyarakat dalam pengembangan wisata Tirtasari Sonsang Kabupaten Agam

Kajian dan analisis terhadap partisipasi masyarakat dalam pengembangan wisata Tirtasari Sonsang perlu dilakukan agar pengembangan wisata tersebut dapat berjalan secara efektif.

\section{Metode}

Metode yang digunakan dalam peneltian ini adalah metode kualitatif dengan teknik analisis deskriptif kualitatif. Data diperoleh dari hasil wawancara mendalam dengan informan yang dipilih dengan menggunakan teknik purposive sampling dan snowball sampling. Purposive 
sampling adalah teknik penentuan informan sebagai sumber data berdasarkan pertimbangan atau tujuan tertentu, yang mana dalam penelitian ini informan tersebut akan menjadi informan kunci yang akan membantu menentukan informan selanjutnya dalam teknik snowball sampling. Teknik snowball sampling merupakan teknik penentuan informan berdasarkan petunjuk informan awal atau informan kunci [10]. Informan kunci dalam penelitian ini adalah kepala desa atau Wali Nagari Koto Tangah dan pengelola Wisata Tirtasari Sonsang. Berdasarkan petunjuk dan arahan dari kedua informan kunci tersebut baru dapat ditentukan informan selanjutnya. Informan yang didapatkan dalam penelitian ini terdiri atas enam orang yang dianggap mewakili setiap kelompok kepentingan dalam pengembangan wisata Tirtasari Sonsang. Informan-informan tersebut dapat dilihat dalam Tabel 1.

Tabel 1. Daftar nama informan.

\begin{tabular}{lll}
\hline \multicolumn{1}{c}{ Informan } & \multicolumn{1}{c}{ Nama } & \multicolumn{1}{c}{ Keterangan } \\
\hline Informan 1 & Mashuri & Kepala desa atau Wali Nagari Koto Tangah \\
Informan 2 & Zulfahren & Anggota pengurus objek wisata Tirtasari Sonsang \\
Informan 3 & Yani Yulmaison & Wali Jorong Sonsang \\
Informan 4 & Samsurizal & Ketua Pengurus objek wisata Tirtasari Sonsang \\
Informan 5 & Helwati & Bundo Kanduang Jorong Sonsang \\
Informan 6 & Nyiak Mangguang & Ketua Kerapatan Adat Jorong Sonsang \\
\hline
\end{tabular}

Data yang telah didapatkan diolah dengan mereduksi informasi-informasi yang dibutuhkan untuk kemudian dianalisis. Metode analisis data yang digunakan dalam penelitian ini adalah metode analisis deskriptif kualitatif. Metode deskriptif kualitatif yaitu metode yang digunakan untuk memberikan gambaran terhadap objek penelitian berdasarkan fakta-fakta yang ada. Metode analisis data deskriptif kualitatif berguna untuk mengembangkan teori yang telah dibangun dari data yang sudah didapatkan di lapangan [11]. Berdasarkan hasil penyajian data akan didapatkan informasi dan kemudian ditafsirkan sesuai dengan tujuan yang akan dicapai.

\section{Hasil dan pembahasan}

\subsection{Partisipasi masyarakat Jorong Sonsang dalam pengembangan wisata Tirtasari Sonsang} Partisipasi yang diberikan oleh masyarakat dapat dikelompokkan menjadi beberapa bentuk. Steck dalam Damanik dan Weber [5] menggambarkan bentuk partisipasi masyarakat dalam pengembangan wisata berdasarkan sifat partipasi yang diberikan masyarakat. Bentuk partisipasi ini terbagi menjadi tiga kelompok, yaitu partisipasi langsung, tidak langsung, dan partisipasi nol. Partisipasi langsung masyarakat Jorong Sonsang dapat dilihat dari keterlibatan masyarakat sebagai tukang parkir, pengurus wahana, pengelola warung makan, dan sebagainya. Pengelolaan objek wisata Tirtasari Sonsang diatur oleh pengurus yang telah ditunjuk oleh masyarakat dalam musyawarah yang dilaksanakan ketika tahap praperencanaan objek wisata Tirtasari Sonsang. Musyawarah tersebut disebut dengan istilah "Buek Arek" oleh masyarakat Jorong Sonsang. Masyarakat Jorong Sonsang juga terlibat secara langsung dalam promosi objek wisata ini melalui kegiatan festival yang diadakan setiap tahunnya. 
Partisipasi tidak langsung masyarakat Jorong Sonsang dapat dilihat dari kegiatan masyarakat dalam sektor pendukung pariwisata seperti menyediakan atau menyumbangkan lahannya sebagai tempat parkir atau fasilitas pendukung seperti toilet. Partisipasi tidak langsung ini juga dapat dilihat ketika masyarakat bersama-sama memperbaiki jalan menuju lokasi objek wisata. Informan 2 menyebutkan bahwa jalan menuju objek wisata ini diperbaiki bersamasama oleh masyarakat Jorong Sonsang setelah objek wisata ini ramai dikunjungi oleh wisatawan. Sedangkan bentuk partipasi nol tidak ditemukan dalam partisipasi masyarakat karena masyarakat tidak membayar untuk infrastruktur dan pemanfaatan kawasan wisata tersebut.

Bentuk partisipasi lain juga dikemukakan ol eh Wardiyanto dan Baiquni [6]. Bentuk partisipasi berdasarkan Wardiyanto dan Baiquni [6] dapat dikelompokkan menjadi enam bentuk. Pada partisipasi masyarakat Jorong Sonsang hanya ditemukan bentuk partisipasi kemitraan dan mobilisasi dengan kemauan sendiri. Bentuk partisipasi kemitraan terlihat pada kerja sama antara masyarakat dengan pemerintah untuk mengembangkan objek wisata Tirtasari Sonsang. Perumusan serta pengambilan keputusan dilakukan oleh masyarakat bersama dengan pemerintah. Peran pemerintah dalam pengembangan objek wisata ini adalah memberikan bantuan yang dibutuhkan oleh masyarakat. Pemerintah merupakan pihak yang membantu membangun embung ini. Selain itu pemerintah juga memberikan bantuan berupa sepeda air serta lampu taman untuk objek wisata Tirtasari Sonsang.

Masyarakat Jorong Sonsang juga diikutsertakan dalam menentukan keputusan dalam pengembangan objek wisata Tirtasari Sonsang. Masyarakat Jorong Sonsang bersama dengan pemerintah mengubah fungsi dari Embung Tirtasari Sonsang menjadi tempat pemancingan ikan. Pemerintah Kabupaten Agam bersama dengan masyarakat menyebarkan bibit ikan ke dalam embung tersebut. Masyarakat Jorong Sonsang berhak ikut berpartipasi dalam pengembangan Embung Tirtasari Sonsang. Mulai dari proses perencanaannya hingga kepada evaluasi. Masyarakat pun mengelola embung yang dijadikan sebagai kolam pemancingan tersebut.

Bentuk partisipasi masyarakat Jorong Sonsang tersebut kemudian berkembang menjadi bentuk partisipasi tingkat 6 , yaitu mobilisasi dengan kemauan sendiri. Bentuk partisipasi ini digambarkan dengan masyarakat yang dapat mengambil inisiatif dalam menentukan suatu keputusan serta memegang kendali penuh terhadap sumber daya yang dimiliki. Pemerintah hanya berperan sebagai fasilitator dalam tahap ini. Masyarakat Jorong Sonsang sudah dapat merumuskan dan menentukan keputusan sendiri untuk pengembangan objek wisata Tirtasari Sonsang. Hal ini dapat dilihat dari inisiasi masyarakat dalam menambahkan daya tarik dan atraksi yang ada di lokasi objek wisata. Masyarakat Jorong Sonsang memiliki kendali penuh terhadap Embung Tirtasari Sonsang sehingga masyarakat Jorong Sonsang dapat memanfaatkan dan mengeksplorasi Embung Tirtasari Sonsang untuk kepentingan masyarakat Jorong Sonsang.

Bentuk partisipasi masyarakat dalam mengembangkan objek wisata juga dikemukakan oleh France dalam Breugel [7]. France mengelompokkan bentuk partisipasi ini menjadi tujuh kelompok. Bentuk partisipasi yang dapat ditemukan dalam partisipasi masyarakat Jorong 
Sonsang ini adalah interactive participation dan self-mobilization. Bentuk partisipasi interactive participation dapat dilihat dari keikutsertaan masyarakat Jorong Sonsang dalam pengambilan keputusan. Kebudayaan masyarakat Jorong Sonsang juga ditampilkan dalam Festival Sonsang Internasional sebagai promosi sekaligus pelestarian budaya masyarakat. Beberapa pemuda dan pemudi Jorong Sonsang diajarkan tarian tradisional Sumatera Barat sebagai daya tarik ketika festival berlangsung. Promosi melalui Festival Sonsang Internasional ini menarik wisatawan untuk berkunjung sekaligus melestarikan budaya masyarakat yang hampir punah.

Bentuk partisipasi self-mobilization masyarakat Jorong Sonsang dapat dilihat dari kemampuan masyarakat menguatkan dan memperluas kegiatan pengembangan wisata mereka. Masyarakat Jorong Sonsang dalam beberapa kegiatan sudah dapat menentukan sendiri keputusan yang akan diambil, misalnya dalam menentukan atraksi atau daya tarik yang akan ditambah di lokasi objek wisata. Selain itu masyarakat juga sudah mampu memperluas pengembangan wisata melalui Festival Sonsang. Selain itu masyarakat Jorong Sonsang juga telah mampu mengeksplorasi sumberdaya yang dimiliki untuk mengembangkan objek wisata tersebut. Hal ini dapat dilihat dari masyarakat Jorong Sonsang yang selalu memunculkan ide untuk menambah daya tarik objek wisata Tirtasari Sonsang ini. Pemerintah hanya menjadi fasilitator pada pengembangan objek Tirtasari Sonsang ini.

\subsection{Intensitas partisipasi masyarakat dalam pengembangan wisata Tirtasari Sonsang}

Intensitas partisipasi masyarakat dapat digambarkan melalui matriks yang dikembangkan oleh Li et al [8]. Matriks tersebut terdiri atas dua kelompok yaitu cakupan dan intensitas. Cakupan menggambarkan keterjangkauan masyarakat yang terlibat dalam suatu kegiatan apakah telah mewakili seluruh kelompok kepentingan yang ada. Li mengelompokkan cakupan partisipasi tersebut menjadi tiga jenis, yaitu exclusion, partial participation, dan full participation. Pada partisipasi masyarakat Jorong Sonsang, cakupan partisipasi masyarakat dapat dikelompokkan ke dalam full participation. Masyarakat yang terlibat telah mewakili seluruh kelompok kepentingan yang ada, mulai dari pemuda dan pemudi hingga ibu-ibu memiliki peran masing-masing dalam pengembangan wisata Tirtasari Sonsang.

Intensitas menggambarkan sejauh mana keterlibatan masyarakat dalam suatu kegiatan. Partisipasi akan menjadi semakin intens apabila masyarakat dilibatkan secara langsung serta terdapat dialog antar stakeholder yang terlibat secara terbuka dan saling menghormati. Li mengelompokkan intensitas partisipasi menjadi tiga jenis, yaitu exclusion, passive participation, dan active participation. Pada partisipasi masyarakat Jorong Sonsang ini, intensitas partisipasi masyarakat dapat dikelompokkan ke dalam active participation. Masyarakat terlibat secara aktif dalam setiap kegiatan. Masyarakat juga memiliki peran yang sama baik antar masyarakat maupun dengan pemerintah.

Berdasarkan hal tersebut, partisipasi masyarakat Jorong Sonsang dapat dikelompokkan ke dalam skenario kelima dalam matriks cakupan dan intensitas partisipasi. Skenario kelima merupakan partisipasi yang memiliki cakupan partisipasi yang penuh serta intensitas partisipasi yang aktif seperti yang dapat dilihat pada Gambar 1. 


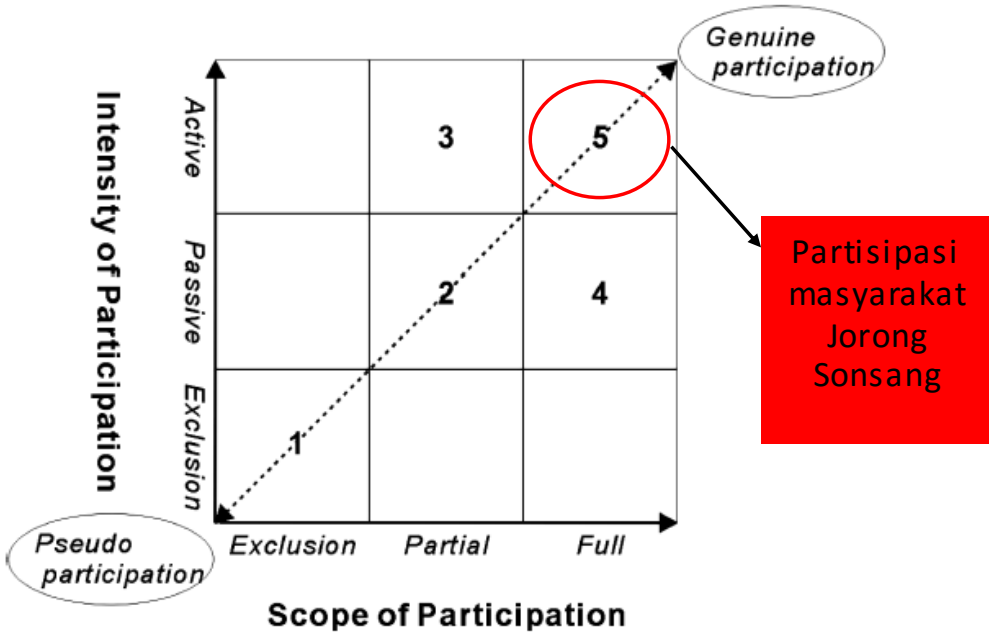

Gambar 1. Matriks cakupan dan intensitas partisipasi masyarakat Jorong Sonsang.

Partisipasi masyarakat Jorong Sonsang ini dapat dikelompokkan ke dalam genuine participation atau skenario kelima. Pada skenario ini, masyarakat memiliki cakupan partisipasi yang luas dan intensitas partisipasi yang aktif. Masyarakat Jorong Sonsang secara keseluruhan terlibat dalam pengembangan objek wisata tersebut. Setiap masyarakat Jorong Sonsang berhak ikut serta dalam mengembangkan objek wisata Tirtasari Sonsang. Tidak terdapat pembatasan atau faktor yang dapat menghalangi masyarakat untuk ikut serta dalam berpartisipasi.

Masyarakat juga diperlakukan sama dalam pengembangan objek wisata ini, baik di antara masyarakat, maupun dengan stakeholder lainnya, seperti pemerintah. Masyarakat dan pemerintah memiliki peran yang sama dalam pengembangan objek wisata ini, misalnya dalam tahap perencanaan. Masyarakat dapat dengan bebas menyampaikan pendapatnya tanpa batasan apapun selama pendapat yang disampaikan tidak bertentangan dengan norma yang berlaku dalam masyarakat. Begitu juga dengan tahapan lainnya. Pelibatan masyarakat dalam setiap kegiatan tersebut menunjukkan bahwa partisipasi masyarakat Jorong Sonsang semakin intens karena masyarakat selalu dilibatkan. Pengembangan objek wisata Tirtasari Sonsang juga bersifat terbuka sehingga seluruh masyarakat dapat mengetahui kegiatan apa saja yang dilakukan untuk mengembangkan objek wisata tersebut.

\subsection{Faktor yang berpengaruh dalam partisipasi masyarakat Jorong Sonsang}

Masyarakat Jorong Sonsang berpartisipasi dalam setiap proses pengembangan objek wisata Tirtasari Sonsang. Mulai dari tahap perencanaan hingga monitoring dan evaluasi melibatkan masyarakat. Sumbangan yang diberikan masyarakat berbeda-beda pada setiap tahapan bergantung pada kebutuhan dan kemampuan masyarakat. Pada tahap perencanaan, monitoring, dan evaluasi masyarakat menyumbangkan tenaga dan buah pikiran, sedangkan pada tahap pelaksanaan masyarakat hampir menyumbangkan seluruh modal dasar manusia yang dimiliki. Berdasarkan hal tersebut faktor yang berpengaruh terhadap partisipasi masyarakat adalah kemampuan masyarakat. Masyarakat memiliki modal dasar yang dibutuhkan dalam pengembangan objek wisata Tirtasari Sonsang, sehingga masyarakat ikut 
berpartisipasi. Masyarakat memiliki modal yang dapat diberikan untuk berpartisipasi, sehingga masyarakat Jorong Sonsang ikut berpartisipasi dalam mengembangkan objek wisata ini.

Selain itu juga terdapat faktor lain yang berpengaruh dalam partisipasi masyarakat Jorong Sonsang dalam mengembangkan objek wisata Tirtasari Sonsang. Hal ini berkaitan dengan intensitas partipasi masyarakat. Masyarakat Jorong Sonsang secara sukarela aktif berpartisipasi dalam mengembangkan objek wisata Tirtasari Sonsang. Hal ini disebabkan karena dorongan dan keinginan masyarakat untuk menghidupkan dan memakmurkan daerah mereka.

Masyarakat secara aktif berpartisipasi karena juga dipengaruhi faktor kendali yang penuh atas sumber daya yang ada khususnya terhadap Embung Tirtasari Sonsang. Masyarakat Jorong Sonsang merasa memiliki Embung Tirtasari secara keseluruhan. Pemerintah juga memberikan kebebasan kepada masyarakat untuk mengeksplorasi Embung Tirtasari Sonsang. Rasa memiliki tersebut mendorong masyarakat untuk terus mengembangkan objek wisata ini, sehingga masyarakat dapat menikmati manfaat dari adanya embung ini. Adanya semangat kegotong-royongan pada masyarakat Jorong Sonsang juga berpengaruh pada partisipasi masyarakat. Tingginya semangat kegotong-royongan masyarakat menyebabkan masyarakat semakin aktif untuk berpartisipasi.

Ada juga msyarakat yang berpartisipasi dalam mengembangkan objek wisata Tirtasari Sonsang untuk meningkatkan pendapatan mereka. Masyarakat yang berpartisipasi dengan tujuan ini biasanya adalah masyarakat golongan pemuda. Masyarakat golongan ini dapat berpartisipasi dengan ikut menjadi pengurus objek wisata Tirtasari Sonsang. Mereka diberi pekerjaan sebagai tukang parkir, mengontrol wahana yang ada, berdagang di sekitar objek wisata, dan sebagainya.

Masyarakat yang bekerja tersebut merupakan masyarakat yang tidak memiliki kemampuan atau skill apapun yang dapat membantu mereka untuk mendapatkan pekerjaan di luar daerah. Dengan adanya objek wisata Tirtasari Sonsang ini, memberikan kesempatan kepada mereka karena adanya lapangan pekerjaan baru. Dengan berpartisipasi ikut mengelola objek wisata Tirtasari Sonsang mereka kemudian akan mendapatkan pendapatan untuk menopang kehidupan mereka.

Selain untuk meningkatkan pendapatan masyarakat yang bekerja tersebut, pengembangan wisata Tirtasari Sonsang ini juga memengaruhi terhadap perekonomian masyarakat secara keseluruhan. Semakin banyak wisatawan yang berkunjung akan semakin membantu masyarakat untuk menghidupkan kembali perekonomian mereka dengan mengembangkan sarana pendukung wisata, seperti homestay, restoran, transportasi, dan sebagainya.

\subsection{Sintesis hasil penelitian}

Masyarakat Jorong Sonsang berpartisipasi secara aktif dalam setiap proses pengembangan objek wisata Tirtasari Sonsang. Dalam setiap kegiatan yang diadakan, masyarakat menyumbangkan modal dasar manusia yang dimiliki oleh masing-masing individu. Pada 
tahap perencanaan, masyarakat banyak menyumbangkan tenaga dan buah pikirannya. Masyarakat berpartisipasi secara langsung dalam sektor pariwisata karena masyarakat menyumbangkan tenaga dan idenya dalam sektor pariwisata. Pada tahap ini masyarakat masih didampingi oleh pemerintah dalam menentukan keputusan. Bentuk partisipasi masyarakat pada tahap ini masuk ke dalam bentuk kemitraan menurut teori Wardiyanto dan Baiquni [6] atau interactive participation menurut teori France dalam Breugel [7].

Masyarakat berperan cukup aktif dalam tahap ini. Seluruh masyarakat terlibat dan menyampaikan sudut pandangnya masing-masing mengenai alternatif pengembangan yang sebaiknya dilakukan. Setiap kegiatan dalam tahap perencanaan ini melibatkan masyarakat karena msayarakat yang paling mengetahui potensi yang dimilikinya. Masyarakat pun memiliki peran yang sama dengan pemerintah. Tidak ada pembatasan bagi masyarakat untuk dapat ikut berpartisipasi dalam tahap ini .

Pada tahap pelaksanaan masyarakat menyumbangkan seluruh modal manusia yang dimiliki sebagai sumber daya untuk mengembangkan objek wisata ini. Tenaga kerja dan keterampilan yang digunakan adalah tenaga dari masyarakat Jorong Sonsang. Masyarakat juga mengusahakan sendiri sebagian dana untuk mengembangkan objek wisata. Masyarakat berpartisipasi secara langsung dalam sektor wisata untuk mengembangkan objek wisata, seperti membangun daya tarik di lokasi, melakukan promosi, dan juga mengelola objek wisata. Partisipasi tidak langsung masyarakat dapat dilihat ketika masyarakat bersama-sama berpartisipasi untuk menyediakan kebutuhan penunjang objek wisata, seperti infrastruktur jalan menuju lokasi objek wisata.

Masyarakat mengusahakan sendiri kebutuhan yang diperlukan dalam tahap ini. Berdasarkan hal tersebut, bentuk partisipasi yang diberikan masyarakat adalah bentuk partisipasi mobilisasi dengan kemauan sendiri atau self-mobilization. Dengan mengusahakan kebutuhan yang diperlukan tersebut, maka masyarakat menjadi penggerak utama dalam tahap ini. Masyarakat dapat berpartisipasi dengan aktif dalam tahap ini. Masyarakat memegang kendali penuh terhadap sumber daya yang dimiliki. Pemerintah juga memberikan kebebasan kepada masyarakat untuk mengelola sendiri objek wisata ini. Dengan demikian seluruh kelompok masyarakat dapat ikut berperan serta dalam kegiatan yang diadakan.

Tahap monitoring dan evaluasi juga sepenuhnya dilakukan oleh masyarakat. Masyarakat secara rutin memantau perkembangan objek wisata Tirtasari Sonsang dengan sesekali mendatangi lokasi objek wisata. Lokasi objek wisata juga dijadikan oleh masyarakat sebagai tempat berkumpul untuk berdiskusi dan saling bertukar pikiran. Pada tahap ini masyarakat juga menyumbangkan tenaga dan buah pikirannya. Bahkan ada juga masyarakat yang sekaligus menyumbangkan harta bendanya ketika memberikan masukan tersebut. Meskipun pemerintah juga ikut mengawasi dan mengevaluasi perkembangan objek wisata ini, namun peran masyarakat lebih mendominasi dalam tahap ini, karena masyarakat dapat dengan langsung menyampaikan idenya. Dengan demikian bentuk partisipasi masyarakat dalam tahap ini juga termasuk ke dalam partisipasi mobilisasi dengan kemauan sendiri. 
Secara keseluruhan masyarakat memiliki peran yang aktif dalam mengembangkan objek wisata Tirtasari Sonsang. Setiap proses pengembangan tersebut lebih banyak diinisiasi oleh masyarakat. Masyarakat juga memiliki kendali yang penuh terhadap embung tersebut. Perlakuan antar masyarakat maupun masyarakat dengan pemerintah adalah sama. Tidak ada pembatasan partisipasi oleh masyarakat. Siapa saja dapat berpartisipasi dalam pengembangan objek wisata ini. Dengan demikian partisipasi masyarakat Jorong Sonsang dalam pengembangan objek wisata ini sudah termasuk ke dalam genuine participation, yang mana masyarakat berperan secara aktif dan bersifat sukarela tanpa ada paksaan dari pihak manapun.

Terdapat berbagai macam faktor yang berpengaruh terhadap partisipasi masyarakat Jorong Sonsang. Faktor yang pertama adalah motivasi masyarakat untuk meramaikan dan memakmurkan daerahnya. Motivasi yang kuat dari masyarakat menyebabkan masyarakat semakin aktif berpartisipasi dalam mengembangkan objek wisata ini, karena dengan berkembangnya objek wisata ini akan semakin menarik wisatawan lain untuk berkunjung, sehingga Jorong Sonsang akan semakin ramai dikunjungi. Faktor rasa memiliki masyarakat terhadap Embung Tirtasari Sonsang juga berpengaruh terhadap partisipasi masyarakat. Kepemilikan masyarakat terhadap embung ini menyebabkan masyarakat akan memelihara dan mengelola dengan baik embung tersebut karena dampaknya secara langsung akan dirasakan oleh masyarakat.

Setelah adanya dorongan berupa motivasi dan rasa memiliki tersebut tentunya masyarakat perlu memberikan apa yang mereka miliki untuk dapat berpartisipasi. Adanya modal dasar manusia tersebut membuat masyarakat dapat berpartisipasi dalam mengembangkan objek wisata ini. Masyarakat berpartisipasi karena masyarakat memiliki kemampuan untuk berpartisipasi. Faktor lain yang juga mempengaruhi masyarakat untuk ikut berpartisipasi adalah keinginan masyarakat untuk meningkatkan pendapatannya. Skema sintesis peneltian ini dapat dilihat pada Gambar 2. 


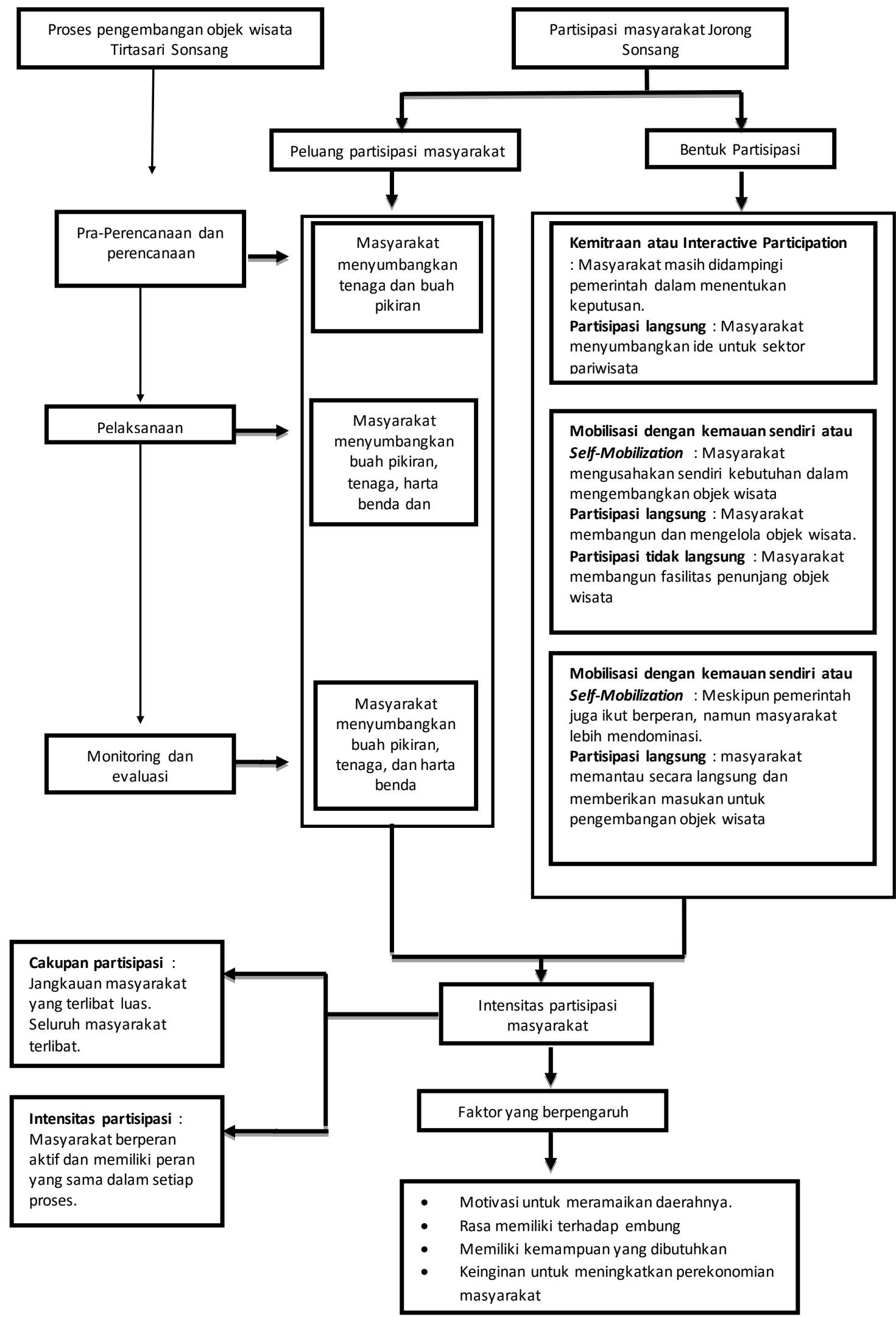

Gambar 2. Skema sintesis hasil penelitian.

Received : October 28, 2019; Accepted: January 23, 2019; Available online: January 30, 2021 


\section{Kesimpulan}

Kesimpulan penelitian mengenai partisipasi masyarakat dalam pengembangan wisata Tirtasari Sonsang Kabupaten Agam adalah sebagai berikut.

1. Partisipasi yang diberikan masyarakat Jorong Sonsang dalam setiap proses pengembangan berbeda-beda sesuai dengan kebutuhan. Pada tahap perencanaan, monitoring dan evaluasi masyarakat menyumbangkan tenaga dan buah pikiran, tahap pelaksanaan masyarakat menyumbangkan tenaga, harta benda, keterampilan dan buah pikiran. Partisipasi yang bersifat langsung dapat dilihat pada setiap proses pengembangan objek wisata, masyarakat secara langsung juga ikut mempromosikan objek wisata Tirtasari Sonsang. Partisipasi tidak langsung masyarakat dapat dil ihat dalam kesediaan masyarakat untuk menyediakan infrastruktur penunjang objek wisata. Bentuk partisipasi masyarakat yang terlihat dalam proses pengembangan objek wisata ini adalah kemitraan dan mobilisasi dengan kemauan atau interactive participation dan self mobilization.

2. Cakupan partisipasi masyarakat Jorong Sonsang telah menjangkau seluruh kelompok kepentingan masyarakat Jorong Sonsang. Setiap kelompok masyarakat memiliki peran masing-masing serta berpartisipasi aktif sesuai dengan kemampuan di setiap tahapnya. Masyarakat kelompok pemuda dan pemudi merupakan kelompok yang banyak berpartisipasi dalam mengembangkan objek wisata.

3. Faktor yang berpengaruh terhadap partisipasi masyarakat dalam mengembangkan objek wisata Tirtasari Sonsang adalah motivasi masyarakat Jorong Sonsang untuk meramaikan kembali daerahnya, rasa memiliki masyarakat terhadap embung, kemampuan masyarakat untuk berpartisipasi, serta keinginan untuk meningkatkan pendapatan

\section{Referensi}

[1] Peraturan Menteri Pariwisata Nomor 14 Tahun 2016 tentang Pedoman Destinasi Pariwisata Berkelanjutan Diakses dari https://www.kemenparekraf.go.id/asset_admin/assets/uploads/media/old_all/PER MEN\%2OPAR\%20No_14\%20Thn\%202016\%20ttg\%20PEDOMAN\%20DESTINASI\%2OP ARIWISATA\%20BERKELANJUTAN_Grda.pdf

[2] Goodwin H dan Santilli R 2009 Community-Based Tourism : A Succes? Tesis (University of Greenwich) Diakses dari https://www.researchgate.net/publication/265278848_CommunityBased_Tourism_a_success_Community-Based_Tourism_a_success

[3] Kontogeorgopoulos N, Churyen A dan Duangsaeng V 2014 Success Factors in Community-Based Tourism in Thailand: The Role of Luck, External Support, and Local Leadership Tourism Planning \& Development 111 pp 106-24 DOI: 10.1080/21568316.2013.852991

[4] Karim S, Kusuma B J dan Amalia N 2018 Tingkat Partisipasi Masyarakat dalam Mendukung Kepariwisataan Balikpapan : Kelompok Sadar Wisata (POKDARWIS) Jurnal Bisnis dan Kewirausahaan 133 pp 144-55 DOI: 10.31940/jbk.v13i3.728

[5] Damanik J dan Weber H F 2006 Perencanaan Ekowisata (dari Teori ke Aplikasi) (Yogyakarta: C.V Andi Offset) 
[6] Wardiyanto dan Baiquni M 2011 Perencanaan Pengembangan Pariwisata (Bandung : CV. Lubuk Agung)

[7] Breugel L V 2013 Community-Based tourism : Local Participation and Perceived Impacts Tesis (Faculty of Social Sciences Radboud University Nijmege)

[8] Li Y, Feng G dan Lai K 2007 The Problem of "Guanxi" for Actualizing Community Tourism : A Case Study of Relationship Networking in China Tourism Geographies 9 2 pp 115-38 DOI: 10.1080/14616680701278489

[9] Dewi M H, Fandeli C dan Baiquni M 2013 Pengembangan Desa Wisata Berbasis Partisipasi Masyarakat Lokasl di Desa Wisata Jatiluwih Tabanan, Bali Kawistara Jurnal Ilmiah Sosial dan Humaniora 32 pp 117-226 Diakses dari https://jurnal.ugm.ac.id/kawistara/article/view/3976/3251

[10] Kaelan 2012 Metode Penelitian Kualitatif Interdisipliner (Yogyakarta: Paradigma)

[11] Sugiyono 2010 Metode Penelitian Kuantitatif, Kualitatif, dan R\&D (Bandung: CV. Alfabeta) 